\title{
Galectin-9 suppresses cholangiocarcinoma cell proliferation by inducing apoptosis but not cell cycle arrest
}

\author{
KIYOYUKI KOBAYASHI ${ }^{1}$, ASAHIRO MORISHITA ${ }^{1}$, HISAKAZU IWAMA $^{2}$, KOJI FUJITA ${ }^{1}$, RYOICHI OKURA ${ }^{1}$, \\ SHINTARO FUJIHARA ${ }^{1}$, TAKUMA YAMASHITA ${ }^{1}$, TAKAYUKI FUJIMORI ${ }^{1}$, KIYOHITO KATO ${ }^{1}$, \\ HIDEKI KAMADA ${ }^{1}$, TOSHIRO NIKI ${ }^{3}$, MITSUOMI HIRASHIMA ${ }^{3}$, KEIICHI OKANO ${ }^{4}$, \\ YASUYUKI SUZUKI ${ }^{4}$ and TSUTOMU MASAKI ${ }^{1}$
}

${ }^{1}$ Department of Gastroenterology and Neurology, ${ }^{2}$ Life Science Research Center, Departments of ${ }^{3}$ Immunology and
${ }^{4}$ Gastroenterological Surgery, Faculty of Medicine, Kagawa University, Miki-cho, Kita-gun, Kagawa 761-0793, Japan

Received April 18, 2015; Accepted June 2, 2015

DOI: 10.3892/or.2015.4197

\begin{abstract}
Cholangiocarcinoma is the most common biliary malignancy and the second most common hepatic malignancy after hepatocellular carcinoma (HCC). Galectin-9 (Gal-9) is a tandem-repeat-type galectin that has recently been shown to exert antiproliferative effects on cancer cells. Therefore, the present study evaluated the effects of Gal-9 on the proliferation of human cholangiocarcinoma cells in vitro as well as the microRNAs (miRNAs) associated with the antitumor effects of Gal-9. Gal-9 suppressed the proliferation of cholangiocarcinoma cell lines in vitro and the growth of human cholangiocarcinoma cell xenografts in nude mice. Our data further revealed that Gal-9 increased caspase-cleaved keratin 18 (CCK18) levels, and the expression of cytochrome $c$ increased in Gal-9-treated cholangiocarcinoma cell lines. These data suggested that Gal-9 induced cholangiocarcinoma cell apoptosis via the intrinsic apoptosis pathway mediated by caspase-dependent or -independent pathways. In addition, Gal-9 reduced the phosphorylation of the epidermal growth factor receptor (EGFR), insulin-like growth factor and insulin-like growth factor-1 receptor (IGF$1 \mathrm{R})$, hepatocyte growth factor receptor and fibroblast growth factor receptor 3 (FGFR3). These findings suggest that Gal-9
\end{abstract}

Correspondence to: Dr Tsutomu Masaki, Department of Gastroenterology and Neurology, Kagawa University Faculty of Medicine/ Graduate School of Medicine, 1750-1 Ikenobe, Miki-cho, Kita-gun, Kagawa 761-0793, Japan

E-mail: tmasaki@med.kagawa-u.ac.jp

Abbreviations: Gal-9, galectin-9; CRDs, carbohydrate-recognition domains; CTLs, cytotoxic T cells; miRNAs, microRNAs; CCK-8, Cell Counting Kit-8; phospho-RTK, phosphorylated receptor tyrosine kinases; EGFR, epidermal growth factor receptor; IGF-1R, insulin-like growth factor-1 receptor; HGFR, hepatocyte growth factor receptor; FGFR3, fibroblast growth factor receptor 3

Key words: cholangiocarcinoma, galectin-9, apoptosis, cell cycle, microRNAs, cytochrome $c$, epidermal growth factor receptor, angiogenesis can be a candidate of therapeutic target in the treatment of cholangiocarcinoma.

\section{Introduction}

Cholangiocarcinoma is the most common biliary malignancy and the second most common hepatic malignancy after hepatocellular carcinoma (HCC) (1). Cholangiocarcinoma accounts for $3 \%$ of all gastrointestinal tumors, and the overall incidence of cholangiocarcinoma appears to have increased over the past 3 decades (2). Hepatobiliary cancers are associated with a poor prognosis since many patients with biliary tract cancers present with advanced disease. The percentage of patients who survive 5 years after diagnosis has not increased during this time period, remaining at $10 \%(3,4)$. Understanding of cholangiocarcinoma biology, the oncogenic landscape of this disease, and its complex interaction with the tumor microenvironment could lead to improved therapies and increased patient survival (5).

Galectin-9 (Gal-9) is a tandem-repeat-type galectin with two carbohydrate-recognition domains (CRDs) and was first identified as an eosinophil chemoattractant and activation factor (6-9). Similar to other galectins, Gal-9 regulates various cellular functions, such as cell aggregation and adhesion, and apoptosis of tumor cells $(9,10)$. Gal-9 enhances antitumor immunity by the initial CRD-independent maturation of dendritic cells and subsequent induction of Th1-mediated antitumor immunity (11). In addition, treatment with recombinant Gal-9 prolonged survival in a murine melanoma model, not only increasing the numbers of CD8 cytotoxic T cells (CTLs) but also those of natural killer (NK) cells and macrophages (12).

Recent studies have uncovered additional mechanisms by which $\mathrm{T}$ cell immunoglobulin mucin-3 (Tim-3), a receptor for Gal-9, negatively regulates $\mathrm{T}$ cell responses by promoting $\mathrm{CD}^{+} \mathrm{T}$ cell exhaustion and inducing expansion of myeloidderived suppressor cells $(13,14)$.

Most studies that investigated the mechanism of $\mathrm{T}$ cell death by Gal-9 were performed using leukemic $\mathrm{T}$ cell lines. Particularly, recombinant Gal-9 induced apoptosis, which depends on the presence of a functional CRD, in various $\mathrm{T}$ cell leukemic cell lines in a dose-dependent manner $(15,16)$. 
Additionally, several in vitro and in vivo studies have indicated that Gal-9 inhibits the growth of multiple myeloma (17) and chronic myeloid leukemia (18). In hematologic malignancies, Gal-9 suppresses cell proliferation and tumor growth in vitro and in vivo. However, in solid malignancies, the antitumor effect of Gal-9 remains unknown.

Less is known concerning the antitumor effects of Gal-9 on cholangiocarcinoma cells and on the microRNAs (miRNAs) associated with these effects. Therefore, the present study aimed to evaluate the effects of Gal-9 on the growth of cholangiocarcinoma cell lines, its mechanism of action, and the miRNAs associated with the antitumor effect of Gal-9.

\section{Materials and methods}

Reagents and antibodies. Recombinant mutant forms of human Gal-9 lacking the linker peptides were expressed and purified as previously described (19). Cell Counting Kit-8 (CCK-8) was purchased from Dojindo Laboratories (Kumamoto, Japan), and all other chemicals were obtained from Sigma Chemical (Tokyo, Japan).

Following antibodies were used: anti- $\beta$-actin monoclonal antibody (A5441, used at a dilution of 1:3,000; Sigma-Aldrich, St. Louis, MO, USA); cyclin D1 (RB-9041, used at 1:1,000); cyclin E (used at 1:1,000) (both from Thermo Fisher Scientific, Waltham, MA, USA); Cdk6 (sc-177, used at 1:1,000); Cdk4 (sc-749, used at 1:1,000); Cdk2 (sc-163, used at 1:2,000) (all from Santa Cruz Biotechnology, Santa Cruz, CA, USA); phosphorylated retinoblastoma protein $(\mathrm{Rb}$; no. 558385, used at 1:1,000; BD Pharmingen); Rb (\#9309, used at 1:1,000; Cell Signaling Technology); and secondary horseradish peroxidase (HRP)-linked anti-mouse and anti-rabbit IgG antibodies (used at 1:2,000; GE Healthcare, UK).

Cell lines and culture. The two human cholangiocarcinoma TFK-1 and HuH-28 cell lines were obtained from the Japanese Cancer Research Resources Bank (Osaka, Japan) and passaged at our laboratory for $<6$ months. The cell lines were authenticated by the Cell Bank using short tandem repeat PCR. TFK-1 was grown in RPMI-1640 and $\mathrm{HuH}-28$ was grown in MEM, with both media types supplemented with $10 \%$ fetal bovine serum (FBS) and $100 \mathrm{mg} / \mathrm{l}$ of penicillin-streptomycin in a humidified atmosphere with $5 \%$ of $\mathrm{CO}_{2}$ at $37^{\circ} \mathrm{C}$.

Cell proliferation assay. Cell proliferation assays were conducted in TFK-1 and HuH-28 cells. Each cell line $\left(5 \times 10^{3}\right)$ was seeded into 96-well plates and cultured in $100 \mu 1$ of culture medium supplemented with 10\% FBS. After $24 \mathrm{~h}$, the cells were treated with $0.03,0.1$ or $0.3 \mu \mathrm{M}$ Gal-9 and then cultured for an additional $48 \mathrm{~h}$. CCK- 8 reagent $(10 \mu \mathrm{l})$ was added to each well, and the plates were incubated at $37^{\circ} \mathrm{C}$ for $3 \mathrm{~h}$. The absorbance of each well was measured at $450 \mathrm{~nm}$ using an auto-microplate reader.

ELISA for apoptosis. M30 Apoptosense enzyme-linked immunosorbent assay (ELISA) kits obtained from PEVIVA AB (Bromma, Sweden) was used to evaluate caspase-cleaved keratin 18 (CCK18) levels (20). Cell line cells $\left(5 \times 10^{3}\right.$ cells) were seeded into 96-well plates and cultured in $100 \mu \mathrm{l}$ of culture medium for $24 \mathrm{~h}$. The cells were then treated with
$0.3 \mu \mathrm{M}$ Gal-9, and the assays were performed according to the manufacturer's instructions. The amount of antigen in controls and samples were calculated by interpolation to a standard curve.

Flow cytometry. To evaluate the mechanism of growth inhibition by Gal-9, cell cycle profiles were analyzed after treatment with Gal-9. TFK-1 cells (1.0x $10^{6}$ cells in a $100-\mathrm{mm}$ dish) were treated with or without $0.3 \mu \mathrm{M}$ Gal-9 for $24 \mathrm{~h}$. The cell cycle distribution was analyzed by measuring the amount of propidium iodide (PI)-labeled DNA in ethanol-fixed cells. Fixed cells were washed with phosphate-buffered saline (PBS) and stored at $-20^{\circ} \mathrm{C}$ until analysis by flow cytometry. On the day of analysis, the cells were washed with cold PBS, suspended in $100 \mu \mathrm{l}$ of PBS plus $10 \mu \mathrm{l}$ of RNase A $(250 \mu \mathrm{g} / \mathrm{ml})$ and incubated for $30 \mathrm{~min}$. To each suspension was added $110 \mu \mathrm{l}$ of PI stain $(100 \mu \mathrm{g} / \mathrm{ml})$, and the cells were incubated at $4^{\circ} \mathrm{C}$ for at least $30 \mathrm{~min}$ prior to analysis. Flow cytometry was performed using a Cytomics FC500 flow cytometer (Beckman Coulter) with an argon laser $(488 \mathrm{~nm})$. The percentages of cells in different phases of the cell cycle were analyzed by FlowJo software (TreeStar, Ashland, OR, USA). All experiments were performed in triplicate to assess consistency of response.

Gel electrophoresis and western blotting. TFK-1 cells $\left(1.0 \times 10^{6} / \mathrm{dish}\right)$ were seeded in $100-\mathrm{mm}$ culture dishes and cultured for $24 \mathrm{~h}$; Gal-9 was added, and the cells were further cultured for $48 \mathrm{~h}$. The cells were washed twice in PBS and lysed using a protease inhibitor cocktail (ProPrep, 'Complete' protease inhibitor mixture; iNtRON Biotechnology, Sungnam, Korea). Protein concentration was quantified using the NanoDrop 2000 fluorospectrometer (Thermo Scientific Corp., USA). Whole-cell lysates (1-10 $\mu \mathrm{g})$ were resolved by SDS-polyacrylamide gel electrophoresis on $10 \%$ Tris-glycine gradient gels by SDS-PAGE (21), and the proteins were transferred to nitrocellulose membranes. After blocking, the membranes were incubated with primary antibodies and then incubated with HRP-conjugated secondary antibodies (22). Immunoreactive proteins were visualized with an enhanced chemiluminescence detection system (Perkin-Elmer Co., Waltham, MA, USA) on X-ray film.

Xenograft model analysis. Animal experiments were performed according to the guidelines of the Committee on Experimental Animals of Kagawa University, Kagawa, Japan.

Eighteen female athymic mice (BALB/c-nu/nu; 6-weeks old; 20-25 g) were purchased from Japan SLC Inc. (Shizuoka, Japan). The animals were maintained under specific pathogen-free conditions using a laminar airflow rack. The mice had continuous free access to sterilized ( $\gamma$-irradiated) food (CL-2; CLEA Japan Inc.) and autoclaved water.

Each mouse was subcutaneously inoculated with TFK-1 cells $\left(5 \times 10^{6}\right.$ cells/animal) in the flank. Two weeks later, the xenografts were identifiable as masses of maximal diameter $>6 \mathrm{~mm}$. We randomly assigned the animals to 3 groups. These groups were treated with $30 \mu \mathrm{g}$ of Gal-9 $(\mathrm{n}=6), 90 \mu \mathrm{g}$ of Gal-9 $(n=6)$ or control (PBS only; $n=6)$.

The Gal-9-treated groups were injected subcutaneously with Gal-9 (30 or $90 \mu \mathrm{g}$ ) 3 times a week. The control group was administered PBS alone. Tumor growth was monitored daily 
by the same investigators (K. Kobayashi and T. Masaki), and tumor size was measured weekly by measuring the 2 largest perpendicular dimensions. Tumor volume was calculated as follows: tumor volume $\left(\mathrm{mm}^{3}\right)=$ [tumor length $(\mathrm{mm}) \mathrm{x}$ tumor width $\left.(\mathrm{mm})^{2}\right] / 2(23)$. All animals were sacrificed 7 weeks after treatment, with all animals remaining alive during this period.

Antibody arrays of apoptosis-related proteins. The Human apoptosis antibody array kit (R\&D Systems, Minneapolis, MN, USA) was used according to the manufacturer's instructions.

Antibody arrays of phosphorylated receptor tyrosine kinases $(p-R T K s)$. Human p-RTKs were assayed using Human p-RTK array kits (R\&D Systems) according to the manufacturer's instructions. Briefly, p-RTK array membranes were blocked with 5\% BSA/TBS (0.01 M Tris-HCl, $\mathrm{pH} 7.6)$ for $1 \mathrm{~h}$ and incubated with $2 \mathrm{ml}$ of lysate prepared from cell lines after normalization so that the amounts of protein were equal. After 3 washes for 10 min each with TBS plus $0.1 \% \mathrm{v} / \mathrm{v}$ Tween-20 and 2 washes for 10 min with TBS alone to remove unbound materials, the membranes were incubated with antiphospho-tyrosine-HRP antibody for $2 \mathrm{~h}$ at room temperature. The unbound HRP antibody was washed out with TBS plus $0.1 \%$ Tween-20. Finally, each array membrane was exposed to X-ray film using a chemiluminescence detection system (Perkin-Elmer Co.).

Angiogenic profile analysis using an antibody array. The RayBio Human Angiogenesis Antibody Array (RayBiotech Inc.) was used according to the manufacturer's protocol. This method is a dot-based assay enabling detection and comparison of 20 angiogenesis-specific cytokines. Each array membrane was exposed to X-ray film using a chemiluminescence detection system.

Analysis of miRNA arrays. Total RNA was extracted from tumor samples using RNeasy Mini kits (Qiagen) according to the manufacturer's instructions. RNA samples typically showed $A_{260 / 280}$ ratios between 1.9 and 2.1, using an Agilent 2100 Bioanalyzer (Agilent Technologies).

After RNA measurement with an RNA 6000 Nano kit (Agilent Technologies), the samples were labeled using a miRCURYHy3/Hy5 Power Labeling kit and were hybridized to a human miRNA Oligo chip (v.19.0; Toray Industries). The chips were scanned with a 3D-Gene Scanner 3000, and the results were analyzed by $3 \mathrm{D}-\mathrm{Gene}$ extraction version 1.2 software (both from Toray Industries). Differences in miRNA expression between Gal-9-treated and control samples were assessed by analyzing the raw data using GeneSpring GX v10.0 (Agilent Technologies). The samples were first normalized relative to $28 \mathrm{~S}$ RNA and baseline corrected to the median of all samples.

Replicate data were consolidated into 2 groups (those from Gal-9-treated cells and those from control cells) and were organized using the hierarchical clustering and ANOVA functions in GeneSpring software. Hierarchical clustering was performed using the clustering function (condition tree) and Euclidean correlation as a distance metric. Two-way ANOVA analysis and asymptotic P-value computation without any error correction on the samples were performed to determine the miRNAs varying most prominently across the groups. The P-value cut-off was set to 0.05 . Only changes $>50 \%$ for at least one of the time points for each sample were considered significant. All analyzed data were scaled by global normalization. The significance of differentially expressed miRNAs was analyzed by the Student's t-test.

Statistical analyses. All statistical analyses were performed using computer-assisted JMP 9.0 (SAS Institute, Cary, NC, USA). Paired analysis between groups used t-tests. A P-value $<0.05$ was considered significant.

\section{Results}

Gal-9 suppresses the proliferation of human cholangiocarcinoma cells. To evaluate the effect of the growth activity of Gal-9 on human cholangiocarcinoma cells in vitro, we examined the effect of Gal-9 on proliferation in two cholangiocarcinoma cell lines, TFK-1 and HuH-28. The cells were grown in $10 \%$ FBS and treated with $0,0.03,0.1$ or $0.3 \mu \mathrm{M}$ Gal-9 for 48 h. Gal-9 led to a dose-dependent and strong inhibition of cell proliferation in the two cholangiocarcinoma cell lines (Fig. 1).

Gal-9 induces apoptosis of cholangiocarcinoma cells. To clarify the mechanism of the growth inhibitory effect of Gal-9, we first examined the induction of apoptosis by Gal-9.

CCK18 expression was determined by ELISA to confirm whether apoptosis is involved in Gal-9-induced cell death. Gal-9 increased the levels of CCK18 in the two CCA cell lines (Fig. 2).

No or little effects of Gal-9 on the cell cycle in TFK-1 cells. It became intriguing to clarify whether effects of Gal-9 on cell cycle are simultaneously involved in the suppression of cholangiocarcinoma cells. The effects of Gal-9 on the expression of various cell cycle-related molecules in TFK-1 cells were evaluated by western blotting. Cells were treated 0 or with $0.3 \mu \mathrm{M}$ Gal-9 for 24-48 $\mathrm{h}$. Assays of the expression of other proteins associated with the $G_{0}$ to $G_{1}$ transition showed that the Cdk6, catalytic subunit of cyclin D1, Cdk2 and Cdk4 were not changed at 24 and $48 \mathrm{~h}$ after the addition of $0.3 \mu \mathrm{M}$ Gal-9 (Fig. 3A).

Next, we performed flow cytometric analysis of the cell cycle to evaluate the contribution of cell cycle arrest to the suppression of CCA cell lines by Gal-9. TFK-1 cells treated with $0.3 \mu \mathrm{M}$ Gal-9 showed no change in the cell cycle profile (Fig. 3B). These results suggested that Gal-9 suppresses cholangiocarcinoma cell growth through the tumor cell apoptosis but not through cell cycle arrest.

Gal-9 suppresses tumor cell growth in vivo. Next experiments were performed to clarify whether Gal-9 also exhibits tumor growth suppressive activity in vivo. Nude mice were injected subcutaneously with TFK-1 cells, followed by the subcutaneous injection of Gal-9. Gal-9 significantly suppressed the tumor growth of TFK-1 cells compared with untreated control mice (Fig. 4A and B). Throughout the in vivo study, Gal-9 had no apparent effects on these mice and did not affect their weights. All animals survived throughout the experiment. 
TFK-1

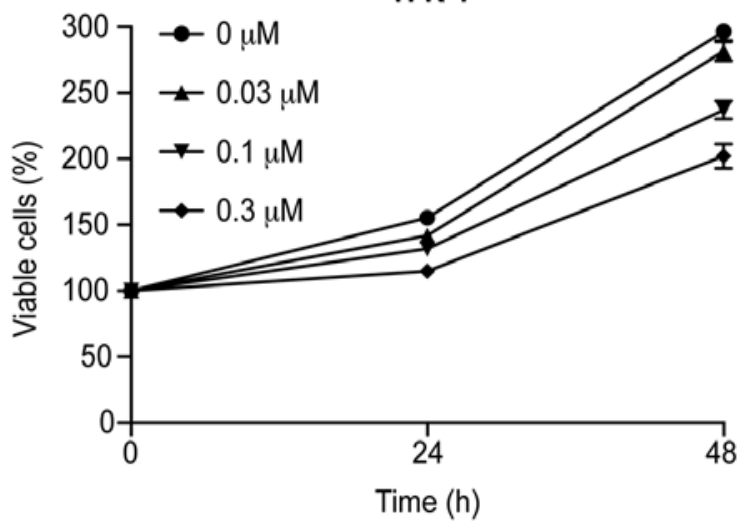

HuH28

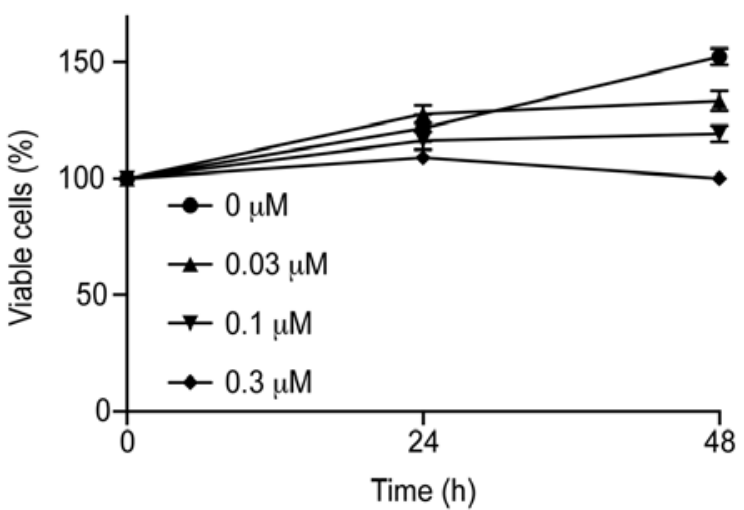

Figure 1. Galectin-9 (Gal-9) inhibits the proliferation of cholangiocarcinoma cell lines. TFK-1 and HuH-28 cells were seeded in 96-well plates. After $24 \mathrm{~h}$, Gal-9 $(0.03,0.1$ or $0.3 \mu \mathrm{M})$ was added to the culture medium. Twenty-four hours after the addition of the agents, the CCK assay was conducted as described in the Materials and methods section. TFK-1 and HuH-28 cells were seeded at 5,000 cells/well in 96-well plates, and the agents were added at time $0 \mathrm{~h}$. The data points represent the mean cell number from 2 independent clusters, and the error bars represent SDs. For each cell line, the conditions at 24 and $48 \mathrm{~h}$ were significantly different than the control $(0 \mathrm{mmol} / \mathrm{l})$.

TFK-1

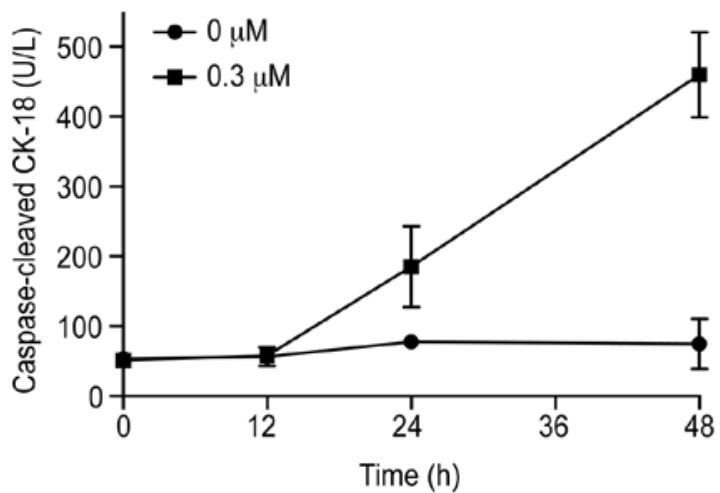

$\mathrm{HuH} 28$

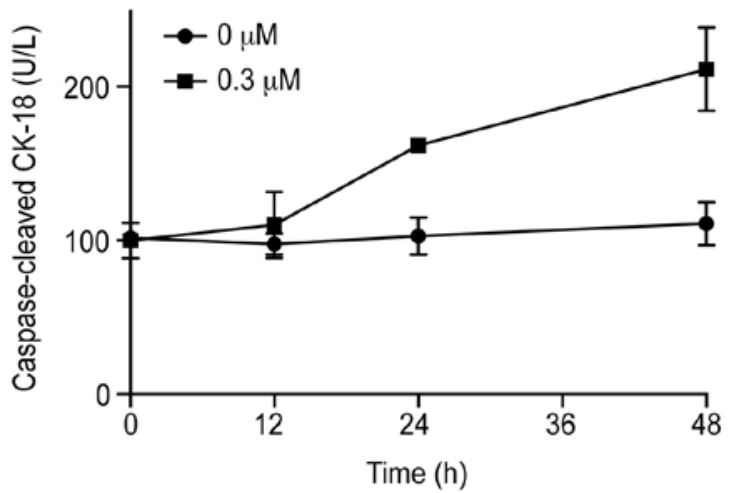

Figure 2. Caspase-cleaved keratin 18 (CCK18) produced specifically during apoptosis was determined by enzyme-linked immunosorbent assay (ELISA). Cells were incubated with or without $0.3 \mu \mathrm{M}$ galectin-9 (Gal-9). Gal-9 increased the levels of CCK18 in TFK-1 and Huh28 cells, suggesting that the apoptotic process following phosphatidylserine exposure proceeds to cut intermediate filaments of cells. Fold-changes in CCK18 are shown as the mean \pm SD with analysis by paired t-test. For each cell line, the conditions at 24 and $48 \mathrm{~h}$ were significantly different than the control $(0 \mathrm{mmol} / \mathrm{l})$.

A

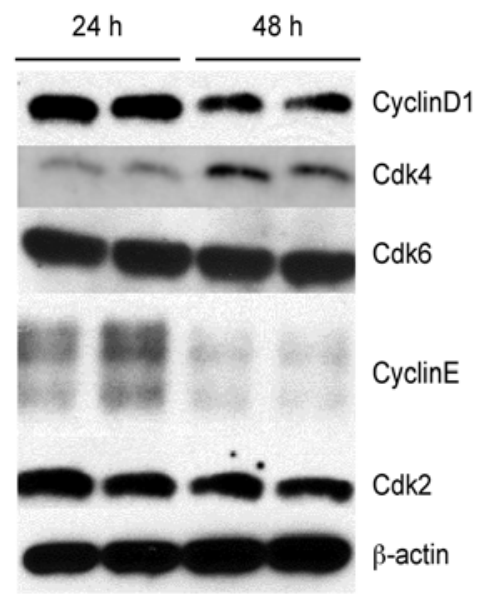

Gal-9
$(+) \quad(-)$

$(+)$
B

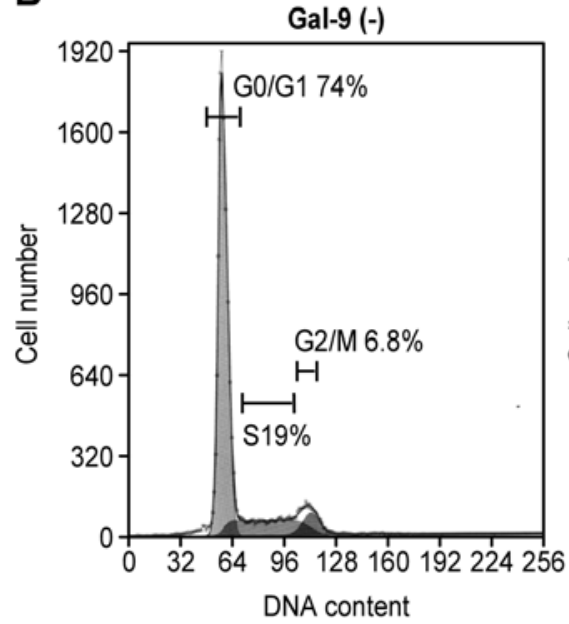

Gal-9 (+)

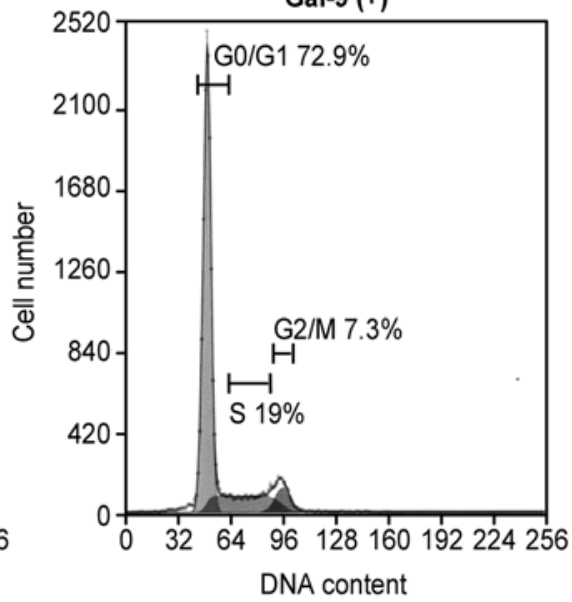

Figure 3. Western blotting and flow cytometric analysis of the cell cycle in TFK-1 cells. (A) The expression levels of cell cycle-related proteins (cyclin D1, Cdk4, Cdk6, cyclin E and Cdk2) in TFK-1 cells after the addition of $0.3 \mu \mathrm{M}$ galectin-9 (Gal-9) did not change compared with that of the control. Protein expression was assayed by western blotting. (B) Flow cytometric analysis of proliferating TFK-1 cells $24 \mathrm{~h}$ after the addition of $0.3 \mu \mathrm{M}$ Gal-9. TFK-1 cells treated with Gal-9 showed no change in the cell cycle profile. 
A

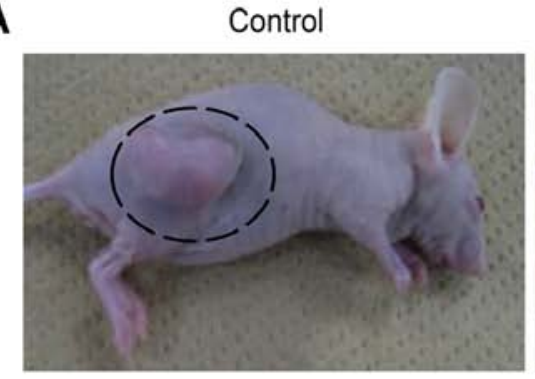

Gal-9 $30 \mu \mathrm{g}$

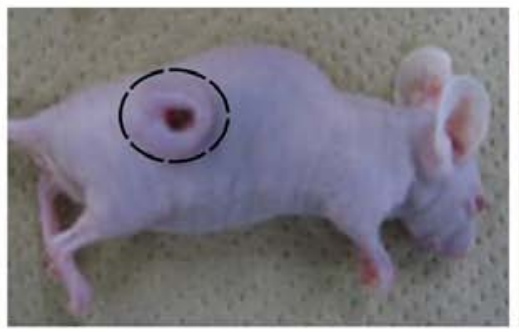

Gal-9 $90 \mu \mathrm{g}$

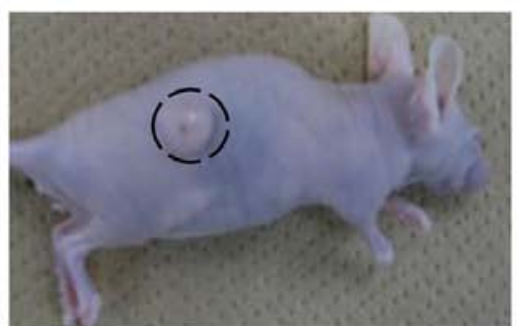

B

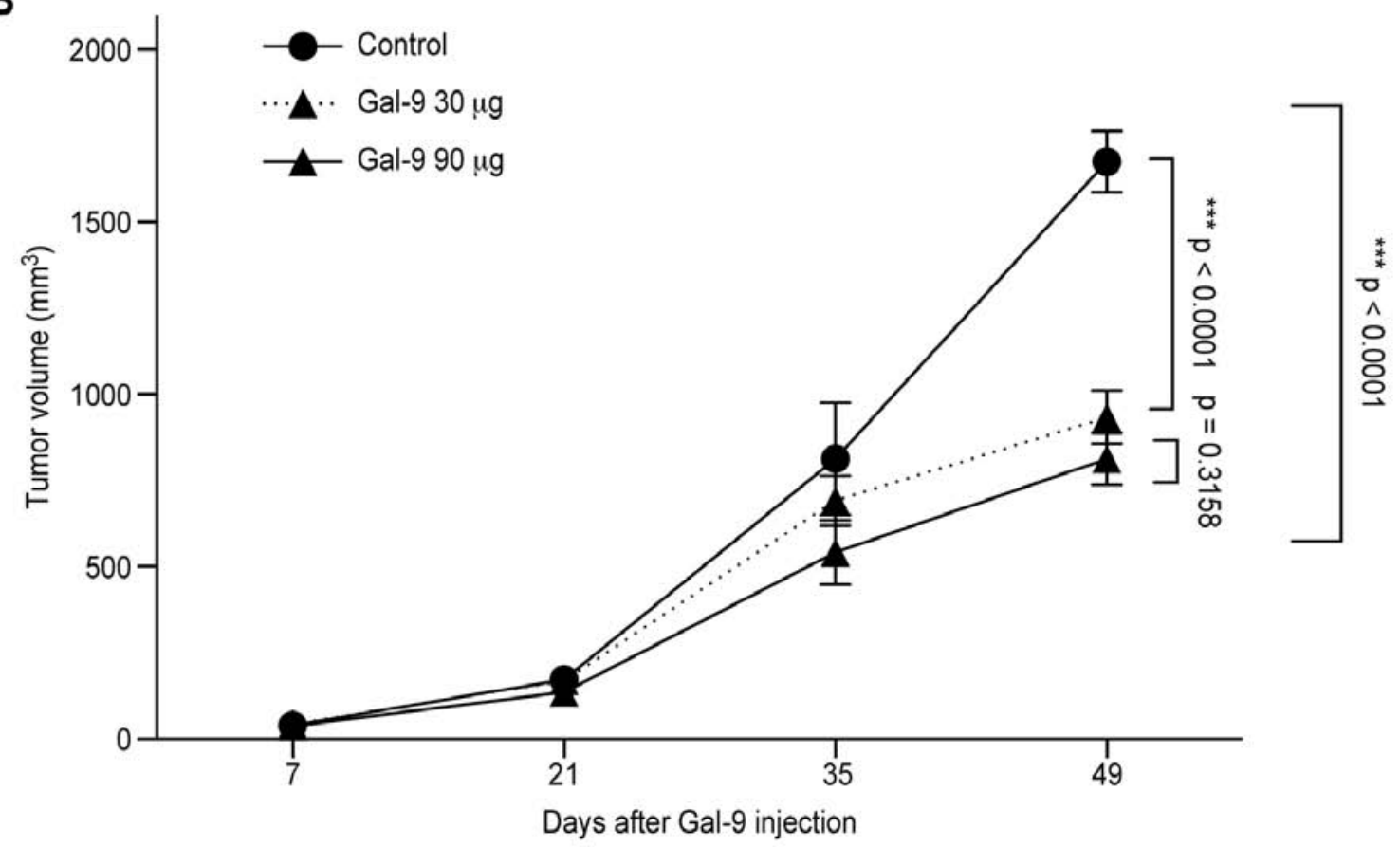

Figure 4. In vivo antitumor effect of galectin-9 (Gal-9) on established cholangiocarcinoma in nude mice. (A) TFK-1 cells were implanted subcutaneously into the flanks of nude mice. When tumors became palpable, 0, 30 or $90 \mu \mathrm{g} \mathrm{Gal}-9$ was injected subcutaneously for 7 weeks, 3 times/week. (B) Tumor volume was calculated as follows: tumor volume $\left(\mathrm{mm}^{3}\right)=\left[\right.$ tumor length $(\mathrm{mm}) \times$ tumor width $\left.(\mathrm{mm})^{2}\right] / 2$. All animals were sacrificed 7 weeks after treatment, with all surviving during this period. The tumors were significantly smaller in Gal-9-treated mice than in control mice. Each point represents the mean \pm SD of 6 animals by two-way ANOVA.

Effects of Gal-9 on apoptosis-associated proteins in TFK-1 cells. We used an apoptosis array system to identify the apoptosis-associated proteins associated with the antitumor effect of Gal-9. Using an antibody array enabled the expression of 35 apoptosis-associated proteins to be screened in TFK-1 cells in the presence and absence of Gal-9 (Fig. 5A). Gal-9 increased the levels of expression of cytochrome $c$ (Fig. 5B). Densitometry analysis showed that the ratio of cytochrome $c$ spots of Gal-9-treated to untreated cells was $249.9 \%$ (Fig. 5C). Expression levels of the apoptosis-associated proteins other than cytochrome $c$ were not affected by Gal-9.

Effects of Gal-9 on p-RTKs in TFK-1 cells. We used a p-RTK array system to identify the key RTKs associated with the antitumor effect of Gal-9. Using an antibody array enabled the expression of 49 activated RTKs to be screened in TFK-1 cells in the presence and absence of Gal-9 (Fig. 6A). Gal-9 reduced the levels of expression of phosphorylated epidermal growth factor receptor (p-EGFR) and phosphorylated insulin-like growth factor-1 receptor (p-IGF-1R), as well as reduced the expression of hepatocyte growth factor receptor (HGFR) and fibroblast growth factor receptor 3 (FGFR3; Fig. 6B). Densitometry analysis showed that the ratio of p-EGFR, p-HGFR, p-IGF-1R and p-FGF R3 spots of Gal-9treated to untreated cells was $40.1,38.0,16.1$ and $18.3 \%$, respectively (Fig. 6C).

Effects of Gal-9 on angiogenesis in TFK-1 cells. We used an angiogenesis array system to identify the key angiogenesisrelated molecules associated with the antitumor activity of Gal-9 on TFK-1 cells (Fig. 7A). The 20 angiogenesis molecules screened showed no change by treatment with Gal-9 (Fig. 7B).

Effects of Gal-9 on miRNA expression in the tumorous tissues in vivo. Using a custom microarray platform, we analyzed the level of 2555 miRNA probe in tumorous tissues in vivo that were treated with and without Gal-9.

In a tumor xenograft model, in the Gal-9 group, there were 22 upregulated and 27 downregulated miRNAs of the 985 miRNAs (GEO, accession no. GSE30289; Table I). 
A

\begin{tabular}{|c|c|c|c|c|c|c|c|c|c|c|c|}
\hline $\begin{array}{c}\text { Reference } \\
\text { Spots }\end{array}$ & & & & & & & & & & & \begin{tabular}{|c}
$\begin{array}{c}\text { Reference } \\
\text { Spots }\end{array}$ \\
\end{tabular} \\
\hline Bad & Bax & $\mathrm{Bcl}-2$ & Bcl-x & $\begin{array}{c}\text { Pro- } \\
\text { Caspase-3 }\end{array}$ & $\begin{array}{c}\text { Cleaved } \\
\text { Caspase-3 }\end{array}$ & Catalase & CIAP-1 & CIAP-2 & Claspin & Clusterin & Ćytochrome \\
\hline $\begin{array}{l}\text { TRAIL } \\
\text { R1/DR4 }\end{array}$ & $\begin{array}{l}\text { TRAIL } \\
\text { R2/DR5 }\end{array}$ & FADD & $\begin{array}{c}\text { Fas/ } \\
\text { TNFRSF6 } \\
\text { ICD95 }\end{array}$ & HIF-1 $1 \alpha$ & $\begin{array}{c}\mathrm{HO}-1 / \\
\text { HMOX1/ } \\
\text { HSP32 }\end{array}$ & $\begin{array}{l}\mathrm{HO}-2 / \\
\text { HMOX2 }\end{array}$ & HSP 27 & HSP 60 & HSP 70 & $\begin{array}{c}\text { HTRA } \\
\text { Omi }\end{array}$ & Livin \\
\hline PON2 & $\begin{array}{l}\text { p21/CIP1/ } \\
\text { CDKN1A }\end{array}$ & P27/Kip1 & $\begin{array}{l}\text { Phospho- } \\
\text { p53(S15) }\end{array}$ & $\begin{array}{l}\text { Phospho- } \\
\text { p53(S46) }\end{array}$ & $\begin{array}{l}\text { Phospho- } \\
\text { p53(S635) }\end{array}$ & \begin{tabular}{|c|} 
Phospho- \\
Rad17 \\
(S635)
\end{tabular} & $\begin{array}{l}\text { SMAC/ } \\
\text { Diablo }\end{array}$ & Survivin & $\begin{array}{l}\text { TNF RI/ } \\
\text { TNF } \\
\text { RSF1A } \\
\end{array}$ & XIAP & $\begin{array}{c}\text { PBS } \\
\text { (negative } \\
\text { control) }\end{array}$ \\
\hline $\begin{array}{l}\text { Reference } \\
\text { Spots }\end{array}$ & & & & & & & & & & & $\begin{array}{c}\text { Reference } \\
\text { Spots }\end{array}$ \\
\hline
\end{tabular}

\section{B}

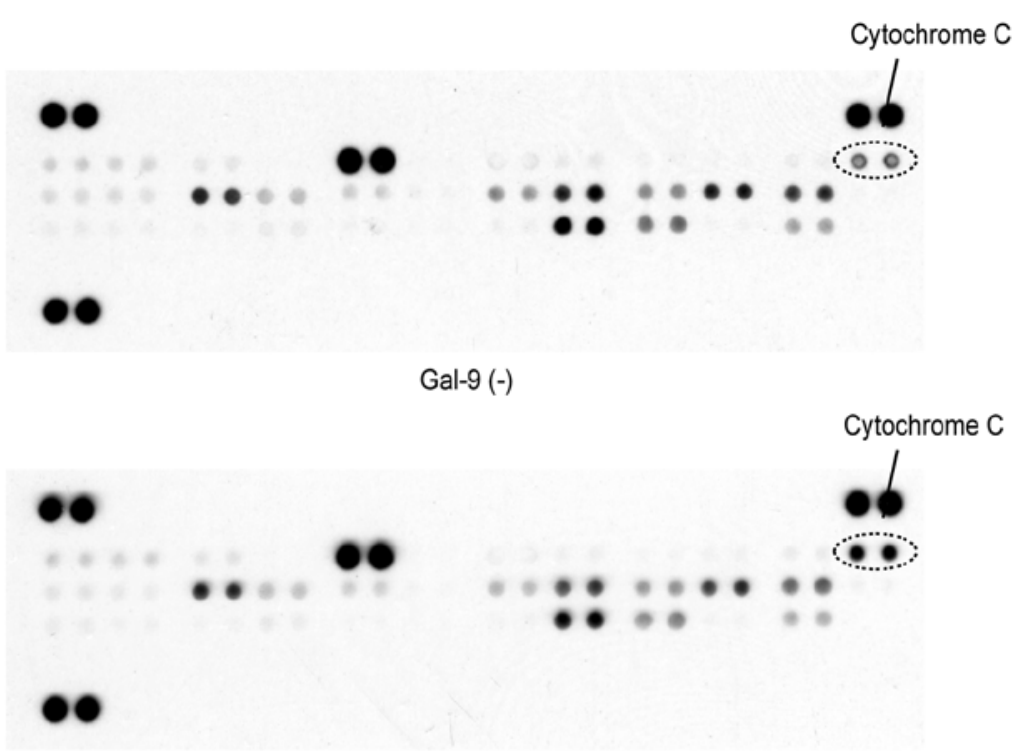

Gal-9 (+)

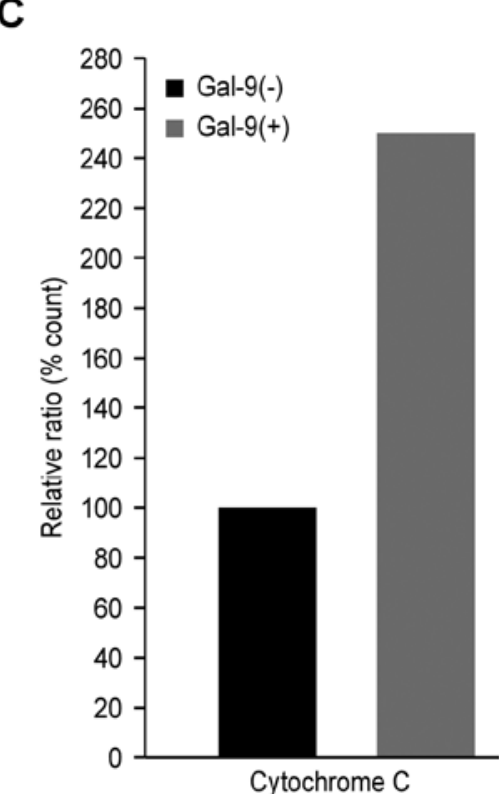

Figure 5. Effects of galectin-9 (Gal-9) on apoptosis-related proteins in TFK-1 cells. (A) Template shows the location of tyrosine kinase antibodies spotted onto a human apoptosis array. (B) Representative expression of various apoptosis-related proteins in TFK-1 cells treated with or without Gal-9 $24 \mathrm{~h}$ after the addition of $0.3 \mu \mathrm{M}$ Gal-9. (C) Densitometry showed that the ratio of cytochrome $c$ spots of Gal-9-treated to untreated cells was $249.9 \%$.

Unsupervised hierarchical clustering analysis using Pearson's correlation showed that tumorous tissues in vivo treated with Gal-9 clustered together, and separately from untreated cell lines (Fig. 8). We found that miR-198 was upregulated in tumor tissues treated with Gal-9.

\section{Discussion}

Our present results revealed that galectin-9 (Gal-9) suppresses cell proliferation and tumor growth of human cholangiocarcinoma cell lines in vitro and in vivo. The antitumor effect of Gal-9 in T cell hemostasis, cell aggregation, and metastasis is well known $(13,14)$. Previous findings suggested that Gal-9 inhibits the proliferation of hematologic malignancies, such as multiple myeloma (17) and chronic myeloid leukemia (18) and significantly retards the tumor growth of myeloma xenografts in mice (17). Cell surfaceassociated Gal-9 triggered the aggregation of melanoma cells, indicative of Gal-9-mediated cellular adhesion and inhibition of cell detachment (24). In hematologic malignancies, Gal-9 suppresses cell proliferation and tumor growth in vitro and in vivo. On the other hand, in solid malignancies, breast cancer cell lines with high levels of endogenous Gal-9 had a strong tendency to aggregate, whereas cells with low levels of Gal-9 did not (25). Importantly, ectopic expression of endogenous Gal-9, as well as treatment with recombinant Gal-9, triggered the formation of tight cellular clusters $(24,25)$. Therefore, Gal-9 directly suppresses cell proliferation and tumor growth, and has therapeutic potential for several solid tumors.

Gal-9 increases Tim- $3^{+}$dendritic cells and $\mathrm{CD} 8^{+} \mathrm{T}$ cells and enhances antitumor immunity via Gal-9-Tim-3 interactions. Nagahara et al reported that mature $\mathrm{CD} 11^{+}$dendritic cells became Tim-3-positive; however, Tim-3-dependent interaction with $\mathrm{CD}^{+}$T-cells triggers the production of IFN- $\gamma$ (26). In line with these in vitro findings, splenocytes of sarcoma-bearing mice that were treated with Gal-9 contained a higher number of 


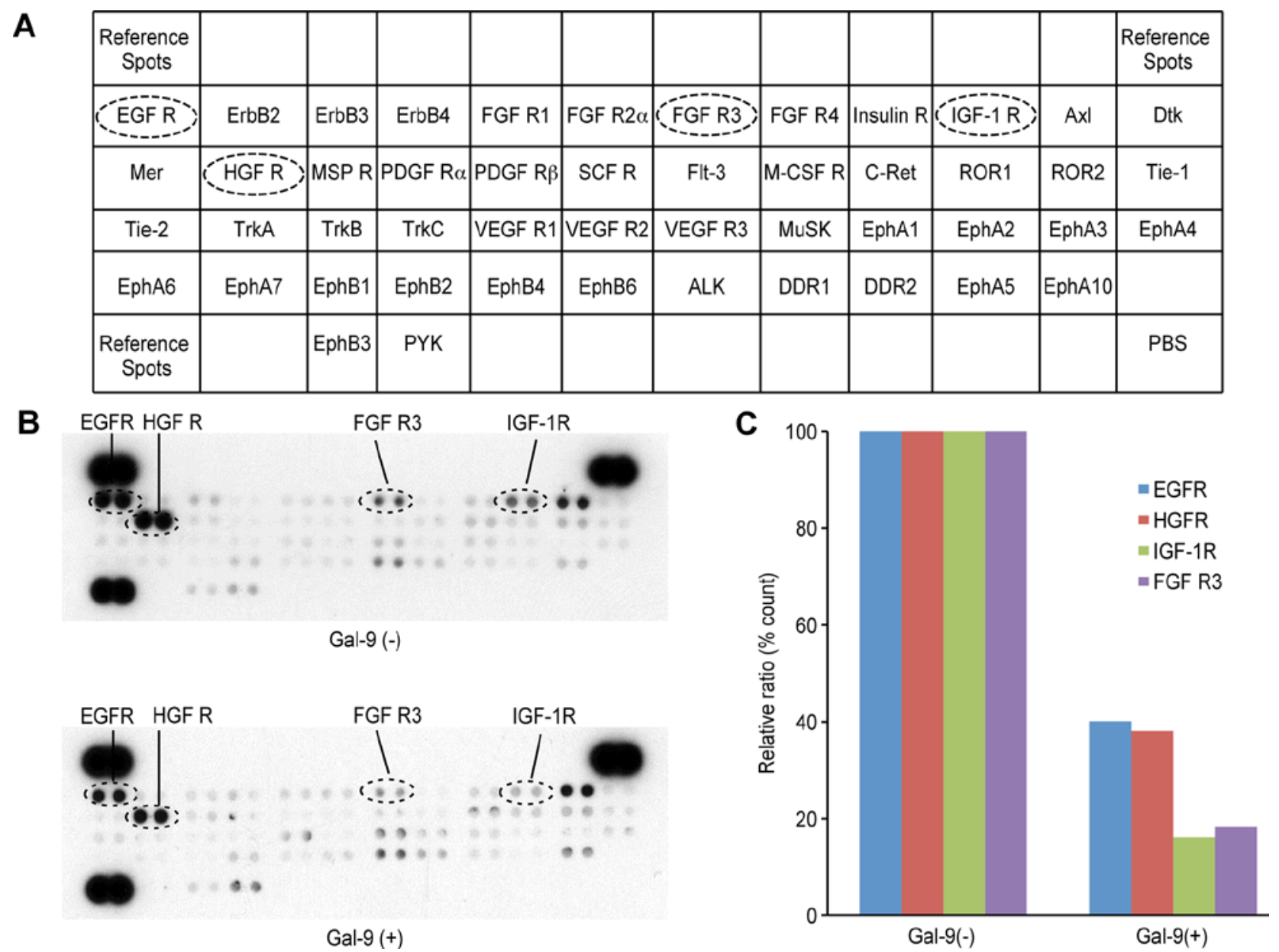

Figure 6. Effects of galectin-9 (Gal-9) on pRTKs in TFK-1 cells. (A) Template shows the location of tyrosine kinase antibodies spotted onto a human phosphoRTK array. (B) Representative expression of various phosphorylated tyrosine kinase receptors in TFK-1 cells treated with or without Gal-9. (C) Densitometry analysis showed that the ratios of phosphorylated epidermal growth factor receptor (p-EGFR), p-HGFR, phosphorylated insulin-like growth factor-1 receptor (p-IGF-1R) and p-FGF R3 spots of Gal-9-treated to untreated cells were 40.1, 38.0, 16.1 and 18.3\%, respectively.

\begin{tabular}{|c|c|c|c|c|c|c|c|}
\hline A Positive & Positive & Negative & Negative & Angiogenin & EGF & ENA-78 & b FGF \\
\hline GRO & IFN- $\gamma$ & IGF-1 & IL-6 & IL-8 & LEPTIN & MCP-1 & PDGF-BB \\
\hline PIGF & RANTES & TGF- $\beta 1$ & TIMP-1 & TIMP-2 & Thrombopoietin & VEGF & VEGF-D \\
\hline & & & & & & Negative & Positive \\
\hline
\end{tabular}

$\mathbf{B}$

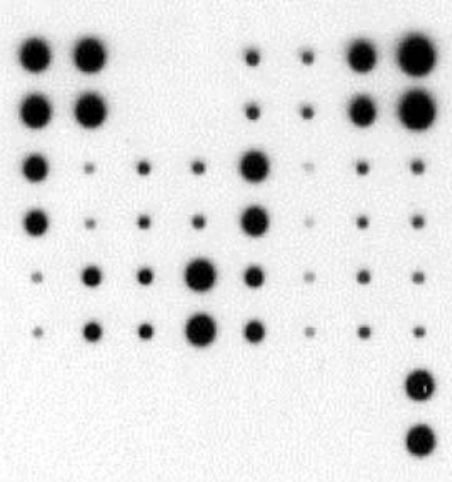

Gal-9 (-)

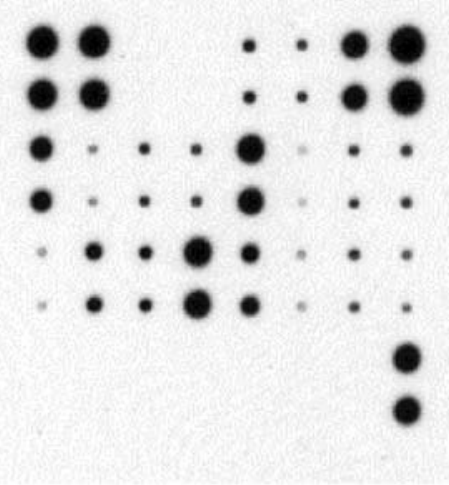

Gal-9 (+)

Figure 7. Effects of galectin-9 (Gal-9) on angiogenesis in TFK-1 cells. (A) Template shows the location of angiogenesis-related proteins spotted onto a human angiogenesis array. (B) The 20 angiogenesis molecules screened showed no change by treatment with Gal-9. 


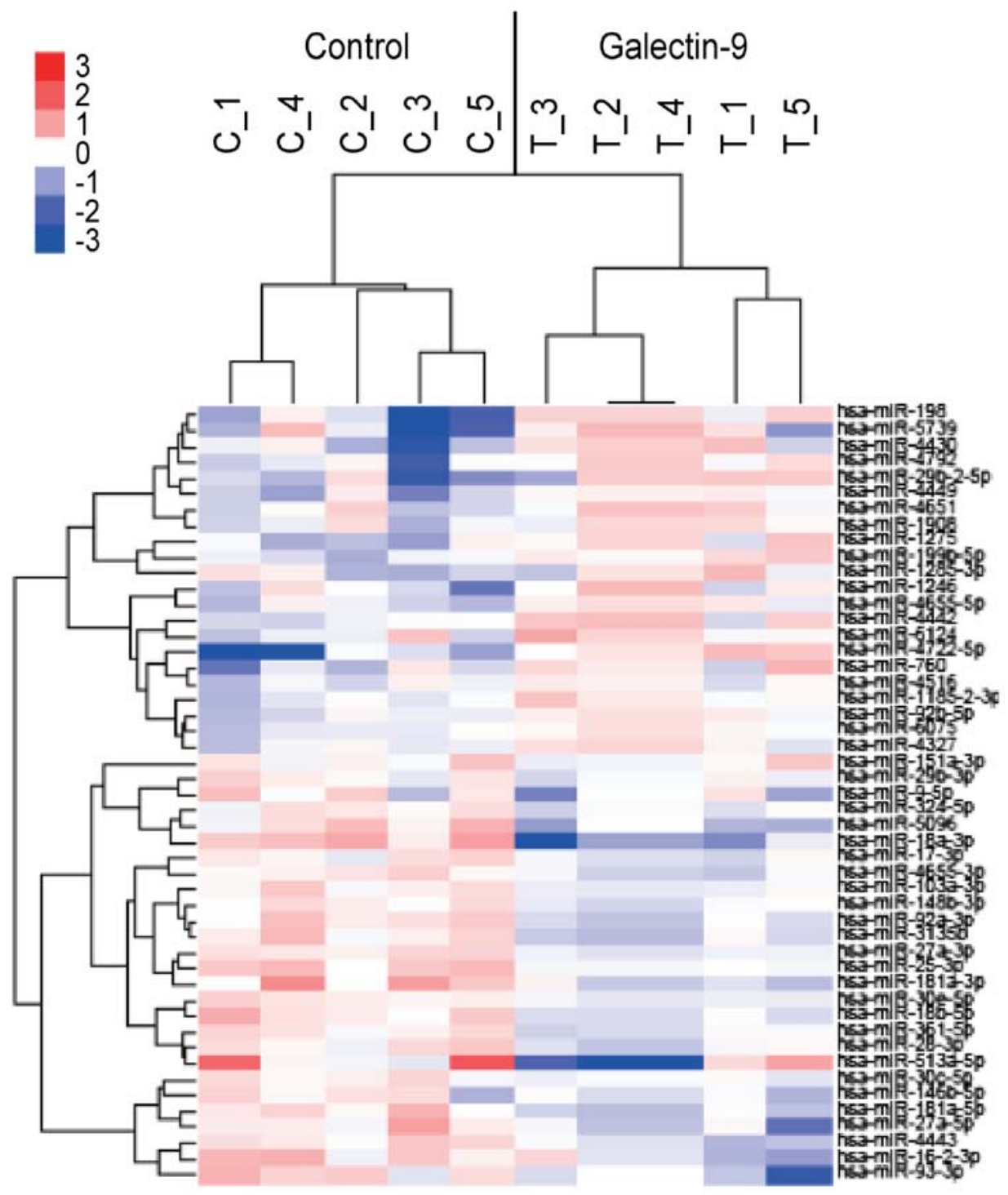

Figure 8. Hierarchical clustering of tumor tissue of TFK-1 cells with and without galectin-9 treatment. Tumor tissues were clustered according to the expression profiles of 49 miRNAs differentially expressed by TFK-1 cells with and without galectin-9. The analyzed samples are shown in the columns, and the miRNAs are presented in rows. The miRNA clustering color scale shown at the top shows the relative expression levels of miRNAs, with red and blue representing high and low expression levels, respectively.

Tim $3^{+} \mathrm{CD} 8^{+}$cytotoxic T cells (CTLs). These CTLs have higher granzyme $\mathrm{B}$ and perforin expression levels, indicative of higher cytotoxic activity (26). We used a xenograft model, resulting in an inhibited immune system due to a greatly reduced number of T cells. Whether Gal-9 suppresses cholangiocarcinoma tumor growth through not depending Gal-9/Tim-3 pathway still needs to be identified in our further study.

Recombinant Gal-9 induces apoptosis and cell death through apoptotic signaling pathways $(17,18)$. Apoptotic signaling was caspase-dependent and induced by the activation of the MAP kinases JNK and p38 in multiple myeloma cells (17). In addition, Gal-9 induced the proapoptotic Bcl-2 family member Noxa via activating transcription factor 3, leading to death in chronic myeloma cells (18). Various hematologic malignancies are sensitive to apoptotic elimination by recombinant Gal-9. Cleavage of cytokeratin 18 (CK18) occurs as an early event during apoptosis following activation of apoptosis executioners, particularly effector caspases, yet remains intact during other types of cell death, such as autophagy or necrosis (27). Therefore, several studies have made use of this phenomenon to detect cellular apoptosis at its early phase (28-30). Our data have suggested that Gal-9 increased the levels of CCK18 in two cholangiocarcinoma cell lines. Additionally, we found that the expression of cytochrome $c$ increased in Gal-9 treated cholangiocarcinoma cell lines using apoptosis array analysis. Cytochrome $c$ released from damaged mitochondria is a very early event in the intrinsic apoptosis pathway and contributes to caspase-9 activation. These data indicate that Gal-9 induces apoptosis of cholangiocarcinoma cell lines in the intrinsic apoptosis pathway through caspase-dependent or -independent pathways.

The expression levels of cell cycle-related proteins ( $\mathrm{Cdk} 2$, Cdk4, Cdk6, cyclin D1 and cyclin E) did not change 24 and $48 \mathrm{~h}$ after the addition of Gal-9. Additionally, flow cytometric analysis showed that Gal-9 did not affect the $G_{0}$ to $G_{1}$ transition in cholangiocarcinoma cells in vitro. These data suggest that the antitumor effect of Gal-9 may not be related to the reduction of various cell cycle-related proteins, particularly 
Table I. Statistical results and chromosomal location of miRNAs in tumorous tissues treated with and without galectin-9.

\begin{tabular}{|c|c|c|c|}
\hline miRNA & $\begin{array}{l}\text { Fold (treated/ } \\
\text { untreated), } \\
\text { mean } \pm \mathrm{SD}\end{array}$ & P-value & $\begin{array}{c}\text { Chromosomal } \\
\text { localization }\end{array}$ \\
\hline \multicolumn{4}{|l|}{ Upregulated } \\
\hline hsa-miR-4722-5p & $2.56 \pm 0.40$ & 0.0418 & 16 \\
\hline hsa-miR-198 & $2.26 \pm 0.30$ & 0.0267 & $3 q 13.33$ \\
\hline hsa-miR-29b-2-5p & $1.87 \pm 0.52$ & 0.0197 & $1 \mathrm{q} 32.2$ \\
\hline hsa-miR-4430 & $1.81 \pm 0.39$ & 0.0310 & 2 \\
\hline hsa-miR-5739 & $1.76 \pm 0.63$ & 0.0472 & 22 \\
\hline hsa-miR-1275 & $1.57 \pm 0.30$ & 0.0495 & 6 \\
\hline hsa-miR-760 & $1.57 \pm 0.40$ & 0.0302 & $1 \mathrm{p} 22.1$ \\
\hline hsa-miR-4792 & $1.56 \pm 0.24$ & 0.0131 & 3 \\
\hline hsa-miR-1246 & $1.51 \pm 0.40$ & 0.0321 & $2 q 31.1$ \\
\hline hsa-miR-4449 & $1.50 \pm 0.08$ & 0.0483 & 4 \\
\hline hsa-miR-4442 & $1.49 \pm 0.31$ & 0.0306 & 3 \\
\hline hsa-miR-199b-5p & $1.39 \pm 0.18$ & 0.0053 & $9 q 34.11$ \\
\hline hsa-miR-4655-5p & $1.39 \pm 0.15$ & 0.0058 & 7 \\
\hline hsa-miR-4651 & $1.37 \pm 0.26$ & 0.0225 & 7 \\
\hline hsa-miR-6124 & $1.37 \pm 0.34$ & 0.0002 & 11 \\
\hline hsa-miR-1185-2-3p & $1.33 \pm 0.19$ & 0.0411 & 14 \\
\hline hsa-miR-1285-3p & $1.31 \pm 0.36$ & 0.0498 & \\
\hline hsa-miR-92b-5p & $1.30 \pm 0.11$ & 0.0401 & $1 q 22$ \\
\hline hsa-miR-1908 & $1.29 \pm 0.17$ & 0.0402 & 11 \\
\hline hsa-miR-4327 & $1.28 \pm 0.19$ & 0.0389 & 21 \\
\hline hsa-miR-6075 & $1.27 \pm 0.11$ & 0.0413 & 5 \\
\hline hsa-miR-4516 & $1.17 \pm 0.13$ & 0.0270 & 16 \\
\hline \multicolumn{4}{|l|}{ Downregulated } \\
\hline hsa-miR-513a-5p & $0.35 \pm 0.02$ & 0.0181 & \\
\hline hsa-miR-181a-3p & $0.10 \pm 0.05$ & 0.0495 & \\
\hline hsa-miR-93-3p & $0.23 \pm 0.46$ & 0.0457 & $7 q 22.1$ \\
\hline hsa-miR-5096 & $0.17 \pm 0.02$ & 0.0219 & 4 \\
\hline hsa-miR-27a-5p & $0.20 \pm 0.04$ & 0.0380 & $19 \mathrm{p} 13.13$ \\
\hline hsa-miR-16-2-3p & $0.20 \pm 0.05$ & 0.0477 & $3 q 25.33$ \\
\hline hsa-miR-181a-5p & $0.11 \pm 0.02$ & 0.0239 & \\
\hline hsa-miR-3135b & $0.12 \pm 0.03$ & 0.0334 & 6 \\
\hline hsa-miR-92a-3p & $0.09 \pm 0.03$ & 0.0276 & \\
\hline hsa-miR-4443 & $0.11 \pm 0.01$ & 0.0072 & 3 \\
\hline hsa-miR-18b-5p & $0.06 \pm 0.01$ & 0.0141 & $\mathrm{Xq} 26.2$ \\
\hline hsa-miR-25-3p & $0.01 \pm 0.02$ & 0.0153 & $7 q 22.1$ \\
\hline hsa-miR-9-5p & $0.27 \pm 0.03$ & 0.0263 & \\
\hline hsa-miR-28-3p & $0.12 \pm 0.00$ & 0.0007 & \\
\hline hsa-miR-4655-3p & $0.10 \pm 0.01$ & 0.0080 & 7 \\
\hline hsa-miR-27a-3p & $0.04 \pm 0.00$ & 0.0006 & $19 \mathrm{p} 13.13$ \\
\hline hsa-miR-361-5p & $0.09 \pm 0.00$ & 0.0011 & $\mathrm{Xq} 21.2$ \\
\hline hsa-miR-148b-3p & $0.08 \pm 0.04$ & 0.0376 & $12 q 13.13$ \\
\hline hsa-miR-30e-5p & $0.02 \pm 0.01$ & 0.0093 & $1 \mathrm{p} 34.2$ \\
\hline hsa-miR-146b-5p & $0.14 \pm 0.03$ & 0.0295 & $10 q 24.32$ \\
\hline hsa-miR-17-3p & $0.09 \pm 0.01$ & 0.0118 & $13 q 31.3$ \\
\hline hsa-miR-103a-3p & $0.05 \pm 0.05$ & 0.0466 & \\
\hline hsa-miR-324-5p & $0.09 \pm 0.00$ & 0.0030 & $17 \mathrm{p} 13.1$ \\
\hline
\end{tabular}

Table I. Continued.

\begin{tabular}{lccc}
\hline & $\begin{array}{c}\text { Fold (treated/ } \\
\text { untreated), } \\
\text { miRNA }\end{array}$ & P-value \pm SD & $\begin{array}{c}\text { Chromosomal } \\
\text { localization }\end{array}$ \\
\hline hsa-miR-30c-5p & $0.05 \pm 0.04$ & 0.0381 & \\
hsa-miR-29b-3p & $0.09 \pm 0.02$ & 0.0197 & \\
hsa-miR-151a-3p & $0.18 \pm 0.04$ & 0.0378 & $8 \mathrm{q} 24.3$ \\
\hline
\end{tabular}

miRNAs, microRNAs; SD, standard deviation.

cyclin D1. Additionally, the 20 screened angiogenesis molecules showed no change by treatment with Gal-9 in human cholangiocarcinoma cell lines.

In contrast, according to the pRTK array, Gal-9 reduced the levels of expression of phosphorylated epidermal growth factor receptor ( $p$-EGFR) and phosphorylated insulin-like growth factor-1 receptor (p-IGF-1R), as well as reduced the expression of HGFR and FGFR3.

miRNAs associated with the antitumor effects of Gal-9 were assessed using miRNA expression arrays. Cluster analyses clearly showed that Gal-9 treatment affected the extent of miRNA expression in tumor tissues. We identified 49 miRNAs that were differentially expressed in a cluster. These miRNAs are meaningful candidates to gauge the effectiveness of Gal-9 treatment and to provide clues to the molecular basis of the anticancer effects of Gal-9, particularly those mediated by miRNAs.

Particularly, miR-198 is downregulated in hepatocellular carcinoma (HCC) compared with the normal liver (31), and it plays a tumor suppressor role by negatively regulating the HGF/c-Met pathway (32). miR-198 inhibits cell proliferation and tumor growth in lung cancer cellular proliferation and induces apoptosis through targeting FGFR1 in lung cancer cells (33). Reduced miR-198 expression is associated with poor prognosis, and high miR-198 predicts better prognosis and increased survival in pancreatic cancer (34). Therefore, the possibility cannot be excluded that miR-198 is closely associated with induction of apoptosis by Gal-9.

In conclusion, our results revealed that Gal-9 inhibits human cholangiocarcinoma cell proliferation and tumor growth, possibly by inducing apoptosis to produce cytochrome $c$, which is an apoptosis-related molecule through the alteration of miRNAs. These findings suggest that Gal-9 may be a candidate as a new therapeutic target in the treatment of cholangiocarcinoma.

\section{Acknowledgements}

We thank Ms. Noriko Murao and Ms. Kana Ogawa for providing technical assistance.

\section{References}

1. Welzel TM, McGlynn KA, Hsing AW, O'Brien TR and Pfeiffer RM: Impact of classification of hilar cholangiocarcinomas (Klatskin tumors) on the incidence of intra- and extrahepatic cholangiocarcinoma in the United States. J Natl Cancer Inst 98: 873-875, 2006. 
2. Khan SA, Davidson BR, Goldin RD, Heaton N, Karani J, Pereira SP, Rosenberg WM, Tait P, Taylor-Robinson SD, Thillainayagam AV, et al; British Society of Gastroenterology: Guidelines for the diagnosis and treatment of cholangiocarcinoma: An update. Gut 61: 1657-1669, 2012.

3. Everhart JE and Ruhl CE: Burden of digestive diseases in the United States Part III: Liver, biliary tract, and pancreas. Gastroenterology 136: 1134-1144, 2009.

4. Tyson GL and El-Serag HB: Risk factors for cholangiocarcinoma. Hepatology 54: 173-184, 2011.

5. Razumilava $\mathrm{N}$ and Gores GJ: Cholangiocarcinoma. Lancet 383: 2168-2179, 2014.

6. Matsumoto R, Matsumoto H, Seki M, Hata M, Asano Y, Kanegasaki S, Stevens RL and Hirashima M: Human ecalectin, a variant of human galectin-9, is a novel eosinophil chemoattractant produced by T lymphocytes. J Biol Chem 273: 16976-16984 1998 .

7. Matsushita N, Nishi N, Seki M, Matsumoto R, Kuwabara I, Liu FT, Hata Y, Nakamura T and Hirashima M: Requirement of divalent galactoside-binding activity of ecalectin/galectin-9 for eosinophil chemoattraction. J Biol Chem 275: 8355-8360, 2000.

8. Matsumoto R, Hirashima M, Kita H and Gleich GJ: Biological activities of ecalectin: A novel eosinophil-activating factor. J Immunol 168: 1961-1967, 2002.

9. Saita N, Goto E, Yamamoto T, Cho I, Tsumori K, Kohrogi H, Maruo K, Ono T, Takeya M, Kashio Y, et al: Association of galectin-9 with eosinophil apoptosis. Int Arch Allergy Immunol 128: 42-50, 2002.

10. Asakura H, Kashio Y, Nakamura K, Seki M, Dai S, Shirato Y, Abedin MJ, Yoshida N, Nishi N, Imaizumi T, et al: Selective eosinophil adhesion to fibroblast via IFN-gamma-induced galectin-9. J Immunol 169: 5912-5918, 2002.

11. Dai SY, Nakagawa R, Itoh A, Murakami H, Kashio Y, Abe H, Katoh S, Kontani K, Kihara M, Zhang SL, et al: Galectin-9 induces maturation of human monocyte-derived dendritic cells. J Immunol 175: 2974-2981, 2005.

12. Nobumoto A, Oomizu S, Arikawa T, Katoh S, Nagahara K, Miyake M, Nishi N, Takeshita K, Niki T, Yamauchi A, et al: Galectin-9 expands unique macrophages exhibiting plasmacytoid dendritic cell-like phenotypes that activate NK cells in tumor-bearing mice. Clin Immunol 130: 322-330, 2009.

13. Wiersma VR, de Bruyn M, Helfrich W and Bremer E: Therapeutic potential of Galectin-9 in human disease. Med Res Rev 33 (Suppl 1): E102-E126, 2013.

14. Fujihara S, Mori H, Kobara H, Rafiq K, Niki T, Hirashima M and Masaki T: Galectin-9 in cancer therapy. Recent Pat Endocr Metab Immune Drug Discov 7: 130-137, 2013.

15. Kashio Y, Nakamura K, Abedin MJ, Seki M, Nishi N, Yoshida N, Nakamura T and Hirashima M: Galectin-9 induces apoptosis through the calcium-calpain-caspase-1 pathway. J Immunol 170: 3631-3636, 2003.

16. Lu LH, Nakagawa R, Kashio Y, Ito A, Shoji H, Nishi N, Hirashima M, Yamauchi A and Nakamura T: Characterization of galectin-9-induced death of Jurkat T cells. J Biochem 141: $157-172,2007$.

17. Kobayashi T, Kuroda J, Ashihara E, Oomizu S, Terui Y, Taniyama A, Adachi S, Takagi T, Yamamoto M, Sasaki N, et al: Galectin-9 exhibits anti-myeloma activity through JNK and p38 MAP kinase pathways. Leukemia 24: 843-850, 2010.

18. Kuroda J, Yamamoto M, Nagoshi H, Kobayashi T, Sasaki N, Shimura Y, Horiike S, Kimura S, Yamauchi A, Hirashima M, et al: Targeting activating transcription factor 3 by Galectin- 9 induces apoptosis and overcomes various types of treatment resistance in chronic myelogenous leukemia. Mol Cancer Res 8: 994-1001, 2010.
19. Nishi N, Itoh A, Fujiyama A, Yoshida N, Araya S, Hirashima M, Shoji $\mathrm{H}$ and Nakamura T: Development of highly stable galectins: Truncation of the linker peptide confers protease-resistance on tandem-repeat type galectins. FEBS Lett 579: 2058-2064, 2005.

20. Schutte B, Henfling M, Kölgen W, Bouman M, Meex S Leers MP, Nap M, Björklund V, Björklund P, Björklund B, et al: Keratin 8/18 breakdown and reorganization during apoptosis. Exp Cell Res 297: 11-26, 2004.

21. Laemmli UK: Cleavage of structural proteins during the assembly of the head of bacteriophage T4. Nature 227: 680-685, 1970.

22. Towbin H, Staehelin T and Gordon J: Electrophoretic transfer of proteins from polyacrylamide gels to nitrocellulose sheets: Procedure and some applications. Proc Natl Acad Sci USA 76: 4350-4354, 1979.

23. D'Incalci M, Colombo T, Ubezio P, Nicoletti I, Giavazzi R, Erba E, Ferrarese L, Meco D, Riccardi R, Sessa C, et al: The combination of yondelis and cisplatin is synergistic against human tumor xenografts. Eur J Cancer 39: 1920-1926, 2003.

24. Kageshita T, Kashio Y, Yamauchi A, Seki M, Abedin MJ, Nishi N, Shoji H, Nakamura T, Ono T and Hirashima M: Possible role of galectin-9 in cell aggregation and apoptosis of human melanoma cell lines and its clinical significance. Int J Cancer 99: 809-816, 2002.

25. Irie A, Yamauchi A, Kontani K, Kihara M, Liu D, Shirato Y, Seki M, Nishi N, Nakamura T, Yokomise H, et al: Galectin-9 as a prognostic factor with antimetastatic potential in breast cancer. Clin Cancer Res 11: 2962-2968, 2005

26. Nagahara K, Arikawa T, Oomizu S, Kontani K, Nobumoto A, Tateno $\mathrm{H}$, Watanabe $\mathrm{K}$, Niki T, Katoh $\mathrm{S}$, Miyake M, et al: Galectin-9 increases Tim- $3^{+}$dendritic cells and CD8 ${ }^{+} \mathrm{T}$ cells and enhances antitumor immunity via galectin-9-Tim-3 interactions. J Immunol 181: 7660-7669, 2008.

27. Kramer G, Erdal H, Mertens HJ, Nap M, Mauermann J, Steiner G, Marberger M, Bivén K, Shoshan MC and Linder S: Differentiation between cell death modes using measurements of different soluble forms of extracellular cytokeratin 18. Cancer Res 64: 1751-1756, 2004.

28. Linder S: Cytokeratin markers come of age. Tumour Biol 28: 189-195, 2007.

29. Cummings J, Ranson M, Butt F, Moore D and Dive C: Qualification of M30 and M65 ELISAs as surrogate biomarkers of cell death: Long term antigen stability in cancer patient plasma. Cancer Chemother Pharmacol 60: 921-924, 2007.

30. Scott LC, Evans TR, Cassidy J, Harden S, Paul J, Ullah R, O'Brien V and Brown R: Cytokeratin 18 in plasma of patients with gastrointestinal adenocarcinoma as a biomarker of tumour response. Br J Cancer 101: 410-417, 2009.

31. Varnholt $\mathrm{H}$ : The role of microRNAs in primary liver cancer. Ann Hepatol 7: 104-113, 2008.

32. Tan S, Li R, Ding K, Lobie PE and Zhu T: miR-198 inhibits migration and invasion of hepatocellular carcinoma cells by targeting the HGF/c-MET pathway. FEBS Lett 585: 2229-2234, 2011.

33. Yang J,Zhao H, Xin Y and Fan L: MicroRNA-198 inhibits proliferation and induces apoptosis of lung cancer cells via targeting FGFR1. J Cell Biochem 115: 987-995, 2014.

34. Marin-Muller C, Li D, Bharadwaj U, Li M, Chen C, Hodges SE, Fisher WE, Mo Q, Hung MC and Yao Q: A tumorigenic factor interactome connected through tumor suppressor microRNA-198 in human pancreatic cancer. Clin Cancer Res 19: 5901-5913, 2013. 